\section{Palaeodiets of Humans and Fauna at the Spanish Mesolithic Site of El Collado}

Elena Garcia Guixé, Michael P. Richards, and M. Eulàlia Subirà

Unitat d'Antropologia, Departament de Biologia Animal, Biologia Vegetal i Ecologia, Universitat Autònoma de Barcelona, Facultat de Ciències, Edifici C, 08192 Bellaterra (Cerdanyola del Vallès), Barcelona, Spain (elena.garciag@ campus.uab.es) (Garcia-Guixé and Subirà)/Department of Human Evolution, Max Planck Institute for Evolutionary Anthropology, Deutscher Platz 6, Leipzig D-04103 Germany (Richards). 25 XI 05

The first human stable isotope results from the Spanish Levant, from the Mesolithic (ca. $7500 \mathrm{BP}$, Mesolithic IIIA phase) site of El Collado (near Oliva, Valencia) provide evidence for the consumption of marine protein by humans, estimated at approximately $25 \%$ of the dietary protein for some individuals. Isotopic analysis of human remains from other coastal Mesolithic sites in Europe, particularly along the Atlantic coast, also shows significant consumption of marine foods, but the amount of marine food consumed by the El Collado humans was much less than at those sites. This may be because of a different dietary adaptation or because the Mediterranean is much less productive than the Atlantic.

Some of the most successful applications of stable isotope analysis as a method for reconstructing past human diets have focused on the European Mesolithic. This is because carbon $\left(\delta^{13} \mathrm{C}\right)$ and nitrogen $\left(\delta^{15} \mathrm{~N}\right)$ bone collagen isotope ratios are particularly effective in detecting the consumption of marine protein (Schoeninger, De Niro, and Tauber 1983; Chisholm, Nelson, and Schwarcz 1982), and marine foods were an important dietary source for coastal Mesolithic humans. Among the earliest published applications of bone collagen carbon isotope ratios in archaeology was that of Tauber (1981), which showed a great reliance on marine foods by late Mesolithic humans in Denmark. Subsequent isotopic studies of other Mesolithic humans in Denmark (Tauber 1983, 1986; Richards, Price, and Koch 2003) in other areas of Atlantic Europe such as the UK (Richards and Mellars 1998; Schulting and Richards 2002a, 2002b), Portugal (Lubell et al. 1994), and France (Schulting and Richards 2001), and in the Baltic (Lidén 1995) also found significant use of marine foods by coastal Late Mesolithic peoples. Most of these studies have focused on northern Europe, perhaps because there are very few Mesolithic human remains from southern Europe and collagen preservation is generally poor in the warmer southern regions

(C) 2006 by The Wenner-Gren Foundation for Anthropological Research. All rights reserved 0011-3204/2006/4703-0008\$10.00 of Europe. There are, however, isotopic values for Neolithic humans from southern Europe, including mainland Greece (Papathanasiou 2001; Papathanasiou, Larsen, and Norr 2000), Crete (Richards and Hedges n.d.), and Malta (Richards et al. 2001), and these indicate that despite the location of these sites on the Mediterranean, Neolithic humans there had a mainly terrestrial diet. Interestingly, this same pattern is observed in studies of the isotopic values of Neolithic humans in northern Europe, especially on the Atlantic coast (Tauber 1981; Richards and Hedges 1999a). It has been argued that this difference is related to a significant dietary shift at the Mesolithic-Neolithic transition (Richards, Schulting, and Hedges 2003; Richards 2003). However, up to this point it has been impossible to explore any such dietary shift at the Mesolithic-Neolithic transition in the Mediterranean area because isotopic data for Mesolithic humans are lacking. Since the Mediterranean is much less productive than the Atlantic, we may not expect to see the same level of marine food consumption as in northern Europe, which in some regions approaches $100 \%$. However, we might predict that if Mesolithic peoples along the Mediterranean coast were following the same hunter-gatherer subsistence adaptation as Mesolithic people in northern Europe, then marine food should have played a significant role in their diets.

In this paper we present the first Mesolithic isotopic data from the Spanish Levant, from the shell midden site of El Collado, and discuss the data in the larger context of European Mesolithic dietary adaptations.

\section{The El Collado Site}

Mesolithic human remains are scarce and fragmentary in Spain (table 1 and fig. 1). With a total of 15 human burials, the site of El Collado contains the largest Mesolithic sample in the country. The site lies near the city of Oliva, Valencia, about $3 \mathrm{~km}$ from the eastern coast of the Iberian Peninsula. The region has a rich and varied ecosystem, with sea coast, inland rivers and lakes, plains, and mountains. There is evidence of settlement continuity in the area from the Middle Palaeolithic onwards (e.g., at Cova Foradà [Aparicio 1992, 79]), including human remains from the Mesolithic, Neolithic, and later periods.

El Collado is a large open-air shell midden site that was excavated by Aparicio between 1987 and 1989. It yielded a rich Mesolithic industry, faunal remains, and Mesolithic graves (Aparicio 1988, 1989, 1992). The stratigraphy as described by the excavator (Aparicio 1992) consisted of three main units that can be summarized as follows:

Layer 1 (depth ca. $0-1.5 \mathrm{~m}$ ) was characterized by its black soil and had been greatly disturbed by centuries of agricultural activity. It contained mollusk remains and lithic material dominated by trapezoids and microburins with some notched blades. Aparicio $(1992,85)$ ascribed this material to destroyed 
upper portions of Layer 2 and, possibly, to an obliterated horizon from the Mesolithic IIIA-IIIB transition.

Layer 2 (depth ca. 1.5-2.8 m) consisted of a fine, compact, dark brown clayey matrix that became lighter at its base. It was intact and contained a homogeneous Mesolithic IIIA flint industry dominated by flakes and core tools with some scrapers and burins and very few geometric pieces. Mollusk shells were numerous in this layer, with a large proportion from marine species. All of the human burials were found in this layer, and with the exception of burial number 10 the grave cuts extended into Layer 3. There is no mention of any associated grave goods in the excavation report.

Layer 3 was formed by a red clayey soil and was unevenly distributed throughout the site. This layer contained cardium and cockle shells and lithic material consisting of scrapers, burins, and backed blades and ascribed to the Mesolithic I stage (Aparicio 1992, 86).

On the basis of the lithic material, Aparicio $(1992,89)$ placed the Mesolithic occupation of El Collado between 10,000 and $6500 \mathrm{BC}$, with the phase of most intense utilization around 7500-6500 BC. Subsequently, two radiocarbon determinations made on human bone from burial 12 yielded the ages of 7,570 $\pm 160 \mathrm{BP}$ and 7,640 $\pm 120 \mathrm{BP}$ (Aparicio 1992; Pérez-Pérez et al. 1995), which calibrate to 6630-6250 BC (Stuiver and Reimer 1993; Stuiver, Reimer, and Reimer 2005). These dates agree with Aparicio's estimate for the age of Layer 2 and the Mesolithic IIIA stage. Although the date was on burial 12, the fact that all graves originated in same layer suggests that they are all broadly contemporaneous and belong to the Mesolithic IIIA occupation.

The faunal material from Layer 2 indicates the consumption of both marine and terrestrial animal foods. Aparicio $(1988,1989,1992)$ described a wide range of species including mollusks, reptiles, fish, and land mammals. The most abun-

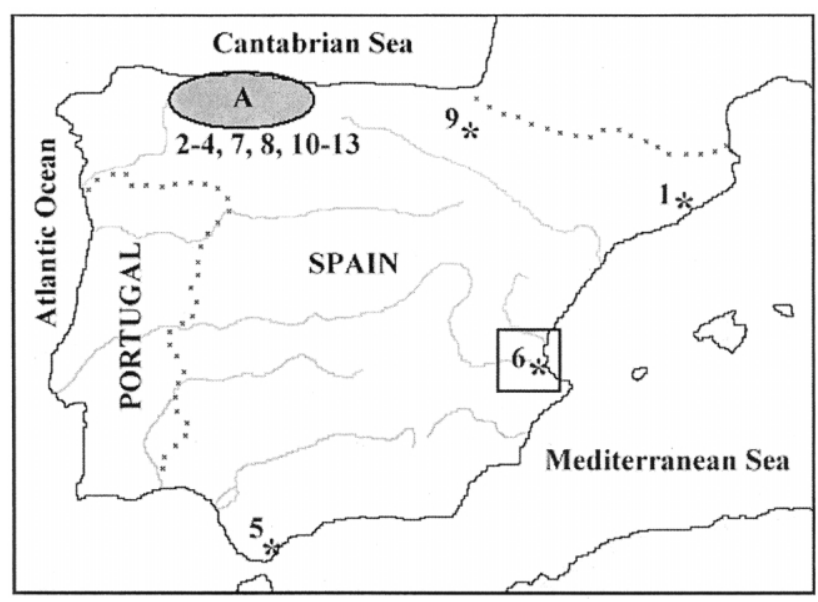

Figure 1. Spanish sites with Mesolithic human remains. 1, Abric del Cingle Vermell (Catalonia); 2, Cueva de Los Azules I (Asturias); 3, Cueva de Balmori (Asturias); 4, Poza l'Egua (Asturias); 5, Cueva de Nerja (Malaga); 6, El Collado (Valencia); 7, Cueva de Colomba (Asturias); 8, Cueva de los Canes (Asturias); 9, Abrigo de Aizpea (Navarre); 10, Cuartamentero (Asturias); 11, Colombres (Asturias); 12, Molino de Gasparín (Asturias); 13, Cueva de Mazaculos II (Asturias); A, Asturias, with a series of closely located sites.

dant remains were those of marine and terrestrial mollusks: marine gastropods (Musex bandaris L., M. trunculus L., Purpura haemastona subsp. Consul Lamk., Triton modiferus Link., Cerithium vulgatum Brug., Columbella rustica L., Nassa reticulata L., Purpura haemastoma L.), freshwater gastropods (Melanopris tricarinata Brug.), terrestrial gastropods (Pseudotachea splendida Drap.), and marine Lamellibranchia (Pectunculos violascense Link., Verus gallina L., Cardium glaucum

Table 1. Key Spanish Mesolithic Sites with Human Remains and Associated Radiocarbon Ages

\begin{tabular}{|c|c|c|c|c|}
\hline Site & $\begin{array}{c}{ }^{14} \mathrm{C} \text { Age BP } \\
\text { (Uncalibrated) }\end{array}$ & $\begin{array}{l}{ }^{14} \mathrm{C} \text { Age } \mathrm{BC} \\
\text { (Calibrated) }\end{array}$ & Human Remains & References \\
\hline Cingle Vermell & $9,760 \pm 160$ & $9400-8835$ & 1 individual & Turbón (1987) \\
\hline \multirow[t]{2}{*}{ Cueva de Los Azules I } & $9,540 \pm 120$ & $9140-8750$ & Postcranial remains from & \multirow{2}{*}{$\begin{array}{l}\text { Garralda (1986), Fernán- } \\
\text { dez-Tresguerres (1976) }\end{array}$} \\
\hline & $9,430 \pm 120$ & $9120-8550$ & 1 individual & \\
\hline Cueva de Balmori & $9,240 \pm ? ?$ & $8640-8290$ & Mandible fragments & Garralda (1989) \\
\hline Poza l'Egua & $8,550 \pm 80$ & $7650-7515$ & Mandible & Drak and Garralda (2005) \\
\hline Cueva de Nerja & $8,260 \pm 360$ & $7600-6700$ & 1 individual & García (1986) \\
\hline \multirow[t]{2}{*}{ El Collado } & $7,570 \pm 160$ & $6590-6250$ & \multirow[t]{2}{*}{15 individuals } & \multirow{2}{*}{$\begin{array}{l}\text { Aparicio }(1988,1989, \\
1992)\end{array}$} \\
\hline & $7,640 \pm 120$ & $6630-6390$ & & \\
\hline Cueva de Colomba & $7,090 \pm 60$ & $6020-5900$ & $\begin{array}{l}\text { Right leg bones from } 1 \\
\text { individual }\end{array}$ & Drak and Garralda (2005) \\
\hline \multirow[t]{2}{*}{ Cueva de Los Canes } & $6,930 \pm 95$ & $5970-5720$ & \multirow[t]{2}{*}{4 individuals } & \multirow{2}{*}{$\begin{array}{l}\text { Arias and Pérez (1992), } \\
\text { Arias and Garralda } \\
\text { (1996) }\end{array}$} \\
\hline & $6,265 \pm 75$ & $5330-5070$ & & \\
\hline Abrigo de Aizpea & $6,600 \pm 50$ & $5620-5490$ & 1 individual & Barandiarán et al. (1998) \\
\hline Cuartamentero & Mesolithic & - & 1 skull & Garralda (1982) \\
\hline Colombres & Mesolithic & - & 1 individual & Clark (1983) \\
\hline Molino de Gasparín & Mesolithic & - & 1 individual & Carballo (1926) \\
\hline Cueva de Mazaculos II & Mesolithic & - & Mandible fragments & Garralda (1981) \\
\hline
\end{tabular}


Brug., C. tuberculatum L. Spondylus gaederopus L., Pecten jacobaens L., Arco noaae). Mammal bones were rare and poorly preserved. The few identified specimens belonged to the Bovidae, Cervidae, Suidae, Rodentiae, and Leporidae families. There was no direct evidence for the contribution of plants to the Mesolithic diet at this site. In contrast to the mammal remains, the human bones were well preserved (fig. 2). The reasons for this difference may be taphonomic. Animal bones were likely deposited on the ground surface and remained exposed for some time, while the humans were buried in the highly basic shell midden. The human remains were studied under the direction of D. Campillo at the Archaeological Museum of Catalonia (Chimenos, Pérez-Pérez, and Lalueza 1991; Pérez-Pérez et al. 1995). Age estimation was based on the degree of mineralization and eruptive phases of teeth in individuals with deciduous or mixed dentitions (Ubelaker 1989) and on dental abrasion in individuals with permanent dentitions (Brothwell 1981; Perizonius 1983). Individuals were identified as one newborn, four subadults (age 12-17 years), and ten adults (age over 18 years), including two classified as mature (age 41-60 years). Sex determination was done on the basis of morphometric traits, especially those of the mandible (Martin and Saller 1957; Ferembach, Schwidetzky, and Stloukal 1979). Seven individuals were identified as males and four as females. Two subadults were probably males, and one adult and the newborn could not be sexed. Only individuals classified as adults were used in the stable isotope analyses (table 2).

\section{Stable Isotope Analysis for Palaeodietary \\ Reconstruction}

The stable carbon and nitrogen isotope ratios of animal tissues and, in particular, bone collagen, can be used to quantify the consumption of foods having different isotopic compositions (DeNiro and Epstein 1978, 1981; Schoeninger and DeNiro

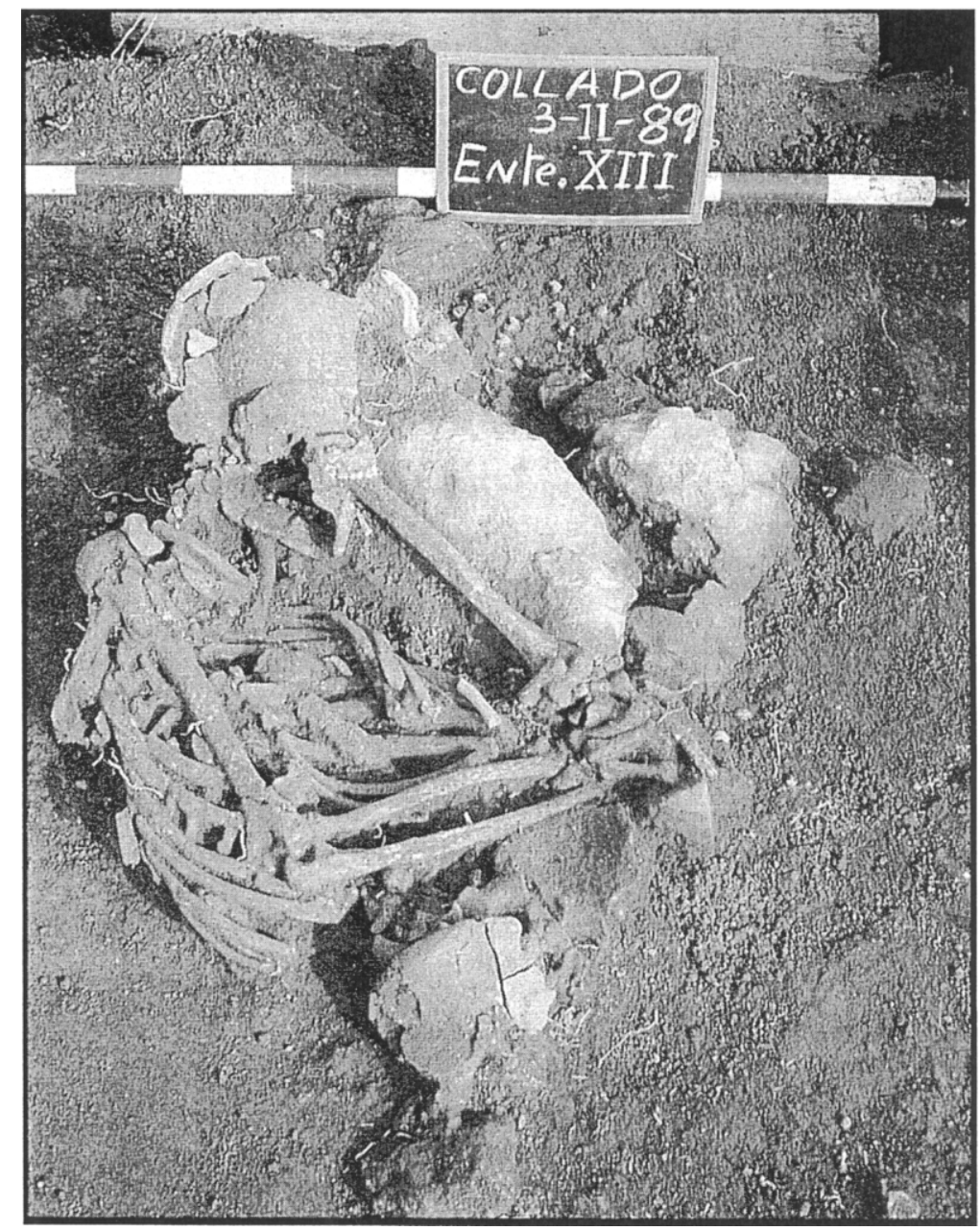

Figure 2. Individual 13 from El Collado. (Photo courtesy of José Aparicio) 
Table 2. Stable Carbon and Nitrogen Isotope Values of Adult Bone Collagen

\begin{tabular}{lcccccr}
\hline Sample No. & Sex & $\delta^{13} \mathrm{C}(\% 0)$ & $\delta^{15} \mathrm{~N}(\%)$ & C:N & $\%$ C & $\%$ N \\
\hline COLL Ind. 1 & Indet. & -19.5 & 10.2 & 3.4 & 23.7 & 8.2 \\
COLL Ind. 2 & Female & -19.1 & 8.9 & 3.3 & 24.9 & 8.9 \\
COLL Ind. 3 & Male & -17.6 & 10.2 & 3.2 & 15.9 & 5.8 \\
COLL Ind. 4 & Male & -17.6 & 12.8 & 3.4 & 24.1 & 8.3 \\
COLL Ind. 5 & Female & -18.2 & 10.6 & 3.3 & 21.7 & 7.6 \\
COLL Ind. 6 & Male & -18.2 & 10.9 & 3.3 & 27.0 & 9.5 \\
COLL Ind. 7 & Female & -17.9 & 8.9 & 3.4 & 29.9 & 10.3 \\
COLL Ind. 12 & Male & -19.0 & 9.5 & 3.5 & 37.0 & 12.5 \\
COLL Ind. 13 & Male & -18.1 & 10.4 & 3.3 & 19.6 & 6.9 \\
\hline
\end{tabular}

1984), although this is largely restricted to the protein components of the diet (Ambrose and Norr 1993). Several major classes of food sources can be distinguished on the basis of their isotopic composition (Ambrose and DeNiro 1986). In terrestrial ecosystems, the $\delta^{13} \mathrm{C}$ values allow differentiation between $\mathrm{C}_{3}$ and $\mathrm{C}_{4}$ plant sources, as well as between marine and terrestrial protein sources (Schoeninger, DeNiro, and Tauber 1983). However, since edible $\mathrm{C}_{4}$ plants are unknown from Mesolithic Europe, $\delta^{13} \mathrm{C}$ values in this context will only be a measure of the marine versus the terrestrial protein component of the diet. The $\delta^{15} \mathrm{~N}$ value indicates the trophic level of the protein consumed, and mammal bone collagen values are $2-4 \%$ o higher than the average value of dietary protein (Schoeninger and DeNiro 1984). In aquatic systems, in which generally there are more steps in the food chain than in terrestrial ecosystems, the $\delta^{15} \mathrm{~N}$ values of top-level consumers are much higher than the values of their terrestrial counterparts. For example, for terrestrial carnivores such as wolves in Europe, we might expect $\delta^{15} \mathrm{~N}$ values of $10 \pm 1 \%$, whereas piscivorous fish can have values of $12 \%$ and marine mammals such as seals values of $15 \%$ (Richards and Hedges 1999b). In freshwater ecosystems the $\delta^{13} \mathrm{C}$ values can mimic terrestrial values or can be more or less enriched, depending on local circumstances such as the input of dissolved carbonates from underlying bedrock. In these freshwater systems, the $\delta^{15} \mathrm{~N}$ values generally follow marine systems, with higher values for top-level consumers than would be found in terrestrial ecosystems.

\section{Methods}

Nine adult individuals were selected for stable isotope analysis, and samples were taken from the diaphyses of long bones. In addition, five bovid bones from the site were sampled for isotopic analysis.

Prior to the analysis, all visible contaminants were removed from the bones with a scalpel, and the bones were then further cleaned through ultrasonication. Collagen extraction procedures followed those outlined in Richards and Hedges $(1999 b)$, with the addition of an ultrafiltration step (Brown, Nelson, and Southon 1988). To summarize, $300 \mathrm{mg}$ of ground bone from each sample was demineralized in $0.5 \mathrm{M} \mathrm{HCl}$ solution for two to three days and then rinsed three times with deionized water until the $\mathrm{pH}$ returned to neutral. Collagen was solubilized by heating the sample to $70^{\circ} \mathrm{C}$ in water at $\mathrm{pH}$ 3. It was then filtered, ultrafiltered $(30 \mathrm{kd})$, frozen, and lyophilized. Isotopic measurements $\left(\delta^{13} \mathrm{C}\right.$ and $\left.\delta^{15} \mathrm{~N}\right)$ of collagen extracts were determined through CF-IRMS (ThermoFinnigan Delta Plus XL coupled with a Carlo Erba elemental analyzer). Stable isotope ratios were expressed relative to the vPDB standard for carbon and atmospheric $\mathrm{N}_{2}$ (AIR) for nitrogen, using the delta $(\delta)$ notation in parts per thousand $(\%)$. Each sample was run in duplicate, and an internal standard was measured with each set of ten samples. All samples discussed here had atomic carbon-to-nitrogen ratios in the range of 3.2-3.5 and therefore retained their in vivo isotopic signatures, according to the criterion proposed by DeNiro (1985) (tables 2 and 3). The data obtained through the chemical investigation were subjected to statistical analyses (SPSS 2001).

\section{Results}

The isotopic data obtained from the El Collado material are given in tables 2 and 3 and presented graphically in figure 3 . Average values for humans and herbivores can be seen in table 4 .

The $\delta^{13} \mathrm{C}$ values for the human remains of El Collado range from -17.6 to $-19.5 \%$ o (with an average of $-18.3 \pm 0.7 \%$ ), and the $\delta^{15} \mathrm{~N}$ values range from 8.9 to $12.8 \%$ (with an average of $10.3 \pm 1.2 \%$ o). To interpret the human $\delta^{13} \mathrm{C}$ and $\delta^{15} \mathrm{~N}$ values we need to determine theoretical end points, defining $\delta^{13} \mathrm{C}$ values that correspond to $100 \%$ terrestrial and $100 \%$ marine protein diets. For northern temperate Europe, a value of $-20 \pm 1 \%$ is a good approximation of the terrestrial end point, whereas $-12 \pm 1 \%$ o defines the marine end point. These values are largely derived from $\delta^{13} \mathrm{C}$ measurements of mammals that have these two dietary extremes (e.g., cattle versus seals) and from isotopic measurements of humans whose diets can be inferred with some confidence (i.e., 100\% terrestrial diets for individuals from agricultural societies buried far inland). There is a temperature effect on the $\delta^{13} \mathrm{C}$ values of plants and, in turn, on those of herbivores and carnivores (van Klinken, van der Plicht, and Hedges 1994). Herbivores from colder regions of Europe, such as Scotland, have $\delta^{13} \mathrm{C}$ values of approximately $-21 \%$, whereas herbivores from

Table 3. Stable Carbon and Nitrogen Isotope Values of Bos Bone Collagen

\begin{tabular}{lcccrr}
\hline Sample No. & $\delta^{13} \mathrm{C}(\% \mathrm{o})$ & $\delta^{15} \mathrm{~N}(\%$ o & C:N & $\%$ C & $\% \mathrm{~N}$ \\
\hline COLL 101 & -19.2 & 6.0 & 3.3 & 12.7 & 4.4 \\
COLL 102 & -19.3 & 5.2 & 3.6 & 7.7 & 2.5 \\
COLL 124 & -19.0 & 5.3 & 3.4 & 14.3 & 4.9 \\
COLL 125 & -19.1 & 5.8 & 3.3 & 12.0 & 4.3 \\
COLL 127 & -18.5 & 6.0 & 3.5 & 25.1 & 8.9 \\
\hline
\end{tabular}




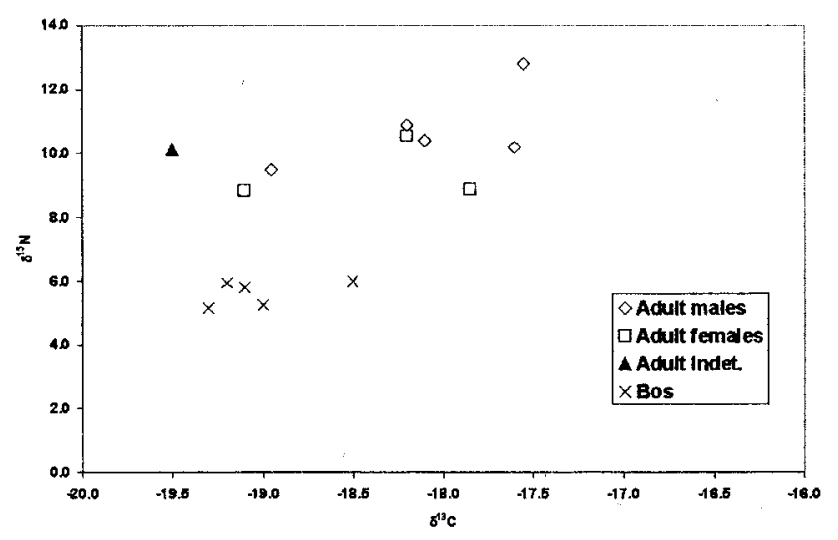

Figure 3. Bone collagen $\delta^{13} \mathrm{C}$ and $\delta^{15} \mathrm{~N}$ values of adult humans and Bos from El Collado.

southern Europe have values closer to - 19\%o (Richards and van Klinken 1997; van Klinken, Richards, and Hedges 2000). To determine terrestrial end points for mammal $\delta^{13} \mathrm{C}$ values for the El Collado site we measured the isotopic values of five bovids. The average $\delta^{13} \mathrm{C}$ value was $-19.0 \pm 0.3 \%$, so we used a theoretical end point for a $100 \%$ terrestrial diet for this region of $-19 \pm 1 \%$. Marine fish and mammals from the Mediterranean have $\delta^{13} \mathrm{C}$ values similar to those of species from the Atlantic (Jennings et al. 1997; Francalacci 1989; Richards and Hedges 1999b), and therefore the theoretical 100\% marine end point is the same, $-12 \pm 1 \%$. We interpret the human $\delta^{13} \mathrm{C}$ values of the El Collado site as indicative of diets with $100 \%$ terrestrial protein for the individuals with values close to $-19 \%$, with those individuals with $\delta^{13} \mathrm{C}$ values close to $-17.5 \%$ o having a marine-protein input into the diet of up to $25 \%$.

It has been observed that the $\delta^{15} \mathrm{~N}$ values of terrestrial herbivores in hot climates can be much higher than those in more temperate environments (e.g., in Egypt [Schwarcz, Dupras, and Fairgrieve 1999] and Turkey [Richards et al. 2003]). However, the El Collado herbivore $\delta^{15} \mathrm{~N}$ average value is 5.6 $\pm 0.4 \%$, which is very similar to that observed for herbivores in other areas of Holocene Europe (e.g., Polet and Katzenberg 2003; Herrscher et al. 2001; Richards 2000). Therefore, we can interpret the human $\delta^{15} \mathrm{~N}$ values as indicators of the sources of terrestrial protein, with an end point of approximately $6 \%$ indicating a $100 \%$ plant protein diet and an end point of $10 \%$ indicating a $100 \%$ animal (herbivore) protein diet. Values that exceed the end point of $10 \%$ will therefore be indicative of the consumption of protein from an aquatic ecosystem. Therefore, both $\delta^{13} \mathrm{C}$ and $\delta^{15} \mathrm{~N}$ values will change with increasing input of marine protein into a largely terrestrial diet, with the $\delta^{13} \mathrm{C}$ values approaching the end point of $-12 \pm 1 \%$ and the $\delta^{15} \mathrm{~N}$ values increasing depending on the source of marine protein. For example, if the protein source is piscivorous fish, we would expect a $\delta^{15} \mathrm{~N}$ end point similar to that for marine mammals, in the range of $15-18 \%$. Turn- ing to the $\delta^{13} \mathrm{C}$ and $\delta^{15} \mathrm{~N}$ human data from El Collado, we observe that there is no uniform diet at this site. Some individuals have a nearly $100 \%$ terrestrial protein diet, largely from animal sources. Other individuals, such as individuals 3 and 4, have clear marine input in their diets. The $\delta^{15} \mathrm{~N}$ values of individuals with significant marine input vary, likely indicating different sources of marine protein. Individual 3, for example, has a $\delta^{15} \mathrm{~N}$ value of $10.2 \%$, which probably reflects the consumption of lower-trophic-level foods such as marine shellfish, whereas individual 4 , with a value of $12.8 \%$, likely consumed higher-trophic-level marine food such as fish. What is clear from these data, however, is that despite the fact that the site is a shell midden, marine foods were not the dominant dietary protein sources at this site. The isotopic values are significantly less enriched than those of Late Mesolithic humans from Denmark and the UK but have affinities with the values from estuarine sites in Portugal (Lubell et al. 1994).

There are no discernible differences in isotope values between males and females at El Collado ( $U$ Mann-Whitney test, $P=0.39$ for $\delta^{13} \mathrm{C}$ and $P=0.25$ for $\left.\delta^{15} \mathrm{~N}\right)$. This is the usual tendency observed in Mesolithic populations in which there are enough individuals to make gender comparisons (e.g., Lillie and Richards 2000), although differences have been observed (Schulting and Richards 2001). However, it is possible to observe graphically a tendency toward lower $\delta^{15} \mathrm{~N}$ values in the female subgroup (fig. 3), which may be related to a more terrestrial diet. We cannot forget that because of the limited size of the human sample, our data set is inadequate to demonstrate gender differences in access to foodstuffs.

\section{Discussion}

The El Collado isotopic data clearly show that marine foods were an important part of the diets of some individuals at this site but not the dominant dietary protein sources despite the site's nature as a shell midden and its coastal location. Interestingly, contemporary earlier Mesolithic humans from both Denmark (e.g., Tybrind Vig, ca. 6,740 BP, $\delta^{13} \mathrm{C}=-$ $17.6 \%$, $\delta^{13} \mathrm{~N}=8.5 \%$ o [Richards, Price, and Koch 2003]) and South Wales (e.g., Potter's Cave 308, ca. 8,580 BP, $\delta^{13} \mathrm{C}=$ $-17.3 \%$ o, $\delta^{15} \mathrm{~N}=13.1 \%$ o [Schulting and Richards 2002a]) also had isotopic values indicative of approximately $25 \%$ marine protein consumption, but this was more mixed. Perhaps the early Mesolithic data from these contexts, including El Collado, are contributing to a picture of early Mesolithic subsistence patterns that conforms to the generally accepted view of mobile hunter-gatherers using a range of seasonally available food resources, including marine foods. Only in the Mesolithic do we see isotopic values indicating large-scale reliance on marine foods. Another explanation for the relatively minor contribution of marine foods in the diets of humans from El Collado as opposed to those in northern Europe may be the less productive nature of the Mediterra- 
Table 4. Average and One Standard Deviation of Stable Carbon and Nitrogen Isotope Values of Human and Bos Bone Collagen

\begin{tabular}{lccc}
\hline & $n$ & $\delta^{13} \mathrm{C}(\% \mathrm{o})$ & $\delta^{15} \mathrm{~N}(\% \mathrm{o})$ \\
\hline Adult males & 5 & $-18.1 \pm 0.6$ & $10.8 \pm 1.2$ \\
Adult females & 3 & $-18.4 \pm 0.6$ & $9.4 \pm 1.0$ \\
All humans & 9 & $-18.3 \pm 0.7$ & $10.3 \pm 1.2$ \\
Bos & 5 & $-19.0 \pm 0.3$ & $5.6 \pm 0.4$ \\
\hline
\end{tabular}

nean versus the Atlantic. It may simply have been impossible to obtain enough marine foods to survive in the Mediterranean area and therefore diets had to be supplemented by terrestrial foods.

To explore the meaning of the El Collado isotopic data further we can compare our results with those for other early prehistoric (pre-Neolithic) humans from the Mediterranean (table 5). There are two published values for Palaeolithic humans, both from the site of Arene Candide in Ligura, Italy Pettitt et al. (2003) found evidence of a marine contribution to the diet of the "Il Principe" Gravettian burial, with isotopic values remarkably similar to those reported here for individual 4. An earlier study of two Late Palaeolithic humans from Arene Candide (ca. 11,000 BP) and two Mesolithic humans from the site of Uzzo Cave, Sicily (ca. 9,000 BP), by Francalacci (1989) did not produce similar results; here the $\delta^{15} \mathrm{~N}$ values indicated a largely animal-protein diet. There appears to have been a range of diets in the Upper Palaeolithic and early Mesolithic in coastal Spain and Italy, with some individuals obtaining their protein largely from terrestrial animal sources while others obtained up to $25 \%$ of their protein from the Mediterranean.

\section{Summary and Conclusions}

Most of the previous isotopic research on the European Mesolithic has been in northern Europe, where there is clear evidence for a marine adaptation, especially in the Late Mesolithic. There are few data from southern Europe as a whole, and the data presented here are similar to those pre sented elsewhere for early Mesolithic humans in northern Europe in pointing to a seasonal dietary adaptation with the use of marine foods during only certain periods of the year. As more data become available we will be better able to compare the Mesolithic dietary adaptations in northern and southern Europe and in Palaeolithic, Mesolithic, and Neolithic populations.

\section{Acknowledgments}

We are grateful to Domènec Campillo, Archaeological Museum of Catalonia, who directed the study of the human remains, and to José Aparicio, Prehistoric Investigation Service of Valencia (S.I.P.), who conducted the excavations of El Collado. We also thank Ken Neal for technical assistance with the isotopic measurements. This project was funded by the Marie Curie Program (ref: HPMT-CT-2001-00271-02, EU).

\section{References Cited}

Ambrose, S. H., and M. J. DeNiro. 1986. Reconstruction of African human diet using bone collagen carbon and nitrogen isotope ratios. Nature 319:321-24.

Ambrose, S. H., and L. Norr. 1993. Experimental evidence for the relationship of the carbon isotope ratios of whole diet and dietary protein to those of bone collagen and carbonate. In Prehistoric human bone: Archaeology at the molecular level, ed. Joseph B. Lambert and Gisela Grupe, 1-37. Munich: Springer-Verlag.

Aparicio, J. 1988. Informe sobre la $1^{a}$ campaña de excavaciones arqueológicas realizadas en el yacimiento mesolítico del Collado (Oliva, Valencia). Valencia: Servicio de Investigación Prehistórica.

- 1989. Informe sobre las excavaciones arqueológicas de urgencia realizadas por este servicio en el yacimiento de El Collado (Oliva, Valencia). Valencia: Servicio de Investigación Prehistórica.

- 1992. Los orígenes de Oliva. Real Academia de Cultura Valenciana, Aula de Humanidades y Ciencias, Serie Histórica 9:75-143.

Arias, P., and M. D. Garralda. 1996. Mesolithic burials in Los Canes Cave (Asturias, Spain). Human Evolution 11:129-38. Arias, P., and C. Pérez. 1992. Las excavaciones arqueológicas

Table 5. Stable Carbon and Nitrogen Values from Two Italian Palaeolithic and Mesolithic Sites

\begin{tabular}{lllrr}
\hline Site & Species & $n$ & $\delta^{13} \mathrm{C}$ (Average) & $\delta^{15} \mathrm{~N}($ Average) \\
\hline Arene Candide (ca. 11,000 BP) & Herbivore & 9 & -19.4 & 4.7 \\
& Human & 2 & -19.5 & 9.0 \\
Arene Candide (ca. 23,500 BP) & Human & 1 & -17.6 & 12.4 \\
Uzzo Cave (ca. 9000 BP) & Herbivore & 2 & -20.9 & 6.2 \\
& Fish & 3 & -10.4 & 10.6 \\
& Cetacean & 2 & -17.1 & $11.8^{\mathrm{a}}$ \\
& Carnivore & 1 & -18.8 & 8.2 \\
& Human & 2 & -21.0 & 10.6 \\
\hline
\end{tabular}

${ }^{a}$ Only one sample for $\delta^{15} \mathrm{~N}$. 
de la Cueva de Los Canes (Arangas, Cabrales): Campañas de 1987 a 1990. In Excavaciones arqueológicas en Asturias 1987-90, 95-101. Asturias: Servicio de Publicaciones del Principado de Asturias.

Barandiarán, I., B. Marti, M. A. del Rincón, and J. L. Maya. 1998. Prehistoria de la Península Ibérica. Madrid: Editorial Ariel.

Brothwell, D. R. 1981. Digging up bones. Oxford: Oxford University Press.

Brown, T. A., D. E. Nelson, and J. R. Southon. 1988. Improved collagen extraction by modified Longin method. Radiocarbon 30:171-77.

Carballo, J. 1926. El esqueleto humano más antiguo de España n.p.

Chimenos, E., A. Pérez-Pérez, and C. Lalueza. 1991. Estudio de la dentición de la serie epipaleolítica de la Oliva (Valencia). In Nuevas perspectivas en antropología, ed. M. C. Botella, S. A. Jimenez, L. Ruiz, and Ph. Du Souich, 189-202. Granada.

$\rightarrow$ Chisholm, B. S., D. E. Nelson, and H. P. Schwarcz. 1982. Stable carbon isotope ratios as a measure of marine versu: $\rightarrow$ terrestrial protein in ancient diets. Science 216:1131-32.

Clark, G. A. 1983. The Asturian of Cantabria: Early Holocene hunter-gatherers in northern Spain. Tucson: University o $\rightarrow$ Arizona Press.

$\rightarrow$ DeNiro, M. J. 1985. Post-mortem preservation and alteration of in-vivo bone collagen isotope ratios in relation to paleodietary reconstruction. Nature 317:806-9.

$\rightarrow$ DeNiro, M. J., and S. Epstein. 1978. Influence of diet on the distribution of carbon isotopes in animals. Geochimica et Cosmochimica Acta 42:495-506.

$\rightarrow-1981$. Influence of diet on the distribution of nitrogen isotopes in animals. Geochimica et Cosmochimica Acta $45 \rightarrow$ 341-51.

Drak, L., and M. D. Garralda. 2005. Mesolithic human remains from Poza L'Egua and Colomba Caves (Asturias, Spain). Abstract presented at the 7th International Conference on the Mesolithic in Europe, Belfast, Northern Ireland, August 29-September 2.

Ferembach, D., I. Schwidetzky, and M. Stloukal. 1979. Empfehlungen für die Altersund Geschlechts diagnose am Skelett. Homo 30:1-32.

Fernández-Tresguerres, J. 1976. Azilian burial from Los Azules I, Asturias, Spain. Current Anthropology 17:769.

Francalacci, P. 1989. Comparison of archaeological, trace element, and stable isotope data from two Italian coastal sites. Rivista di Antropologia 66:239-50.

García, M. 1986. El enterramiento epipaleolítico de la "Cueva de Nerja” (Málaga): Estudio preliminar. Antropología y Paleoecología Humana 4:3-23.

Garralda, M. D. 1981. Las mandíbulas de Balmori y Mazaculo $\rightarrow$ Po II (Asturias): Estudio antropológico. Boletín del Instituto de Estudios Asturianos 103:595-603.

- 1982. El cráneo asturiense de Cuartamentero (Llanes, Oviedo). Kobie 12:7-29.
1986. The Azilian man from Los Azules Cave I (Cangas de Onís, Oviedo, Spain). Human Evolution 1:431-48.

1989. Les populations post-paleolithiques d'Espagne: Morphologie, culture et ecologie. In People and culture in change, ed. I. Hershkovitz, 505-16. British Archaeological Reports International Series 508(i).

Herrscher, E., H. Bocherens, F. Valentin, and R. Colardelle. 2001. Comportements alimentaires au Moyen Âge à Grenoble: Application de la biogéochemie isotopique à la nécropole Saint-Laurent (XIIIe-Xve siècles, Isère, France). Comptes Rendus de l'Académie des Sciences de Paris 324: 479-87.

Jennings, S., O. Reñones, B. Morales-Nin, N. V. C. Polunin, J. Moranta, and J. Coll. 1997. Spatial variation in the ${ }^{15} \mathrm{~N}$ and ${ }^{13} \mathrm{C}$ stable isotope composition of plants, invertebrates, and fishes on Mediterranean reefs: Implications for the study of trophic pathways. Marine Ecology Progress Series 146:109-16.

Lidén, K. 1995. Prehistoric diet transitions. Stockholm: Stockholm University.

Lillie, M., and M. P. Richards. 2000. New radiocarbon dates and palaeodietary evidence from the Ukrainian Mesolithic. Journal of Archaeological Science 27:965-72.

Lubell, D., M. Jackes, H. Schwarcz, M. Knyf, and C. Meiklejohn. 1994. The Mesolithic-Neolithic transition in Portugal: Isotopic and dental evidence of diet. Journal of Archaeological Science 21:201-16.

Martin, R., and K. Saller. 1957. Lehrbuch der Anthropologie. Stuttgart: Gustav Fischer.

Papathanasiou, A. 2001. A bioarchaeological analysis of Neolithic Alepotrypa Cave, Greece. British Archaeological Reports International Series 961.

Papathanasiou, A., C. S. Larsen, and L. Norr. 2000. Bioarchaeological inferences from a Neolithic ossuary from Alepotrypa Cave, Diros, Greece. International Journal of Osteoarchaeology 10:210-28.

Pérez-Pérez, A., E. Chimenos, C. Lalueza, and O. Mercadal. 1995. Human remains from the Mesolithic site of El Collado (Oliva, Valencia, Spain). Homo 45:243-56.

Perizonius, W. R. K. 1983. Esquema de desgaste dentario en premolares, caninos e incisivos, siguiendo el propuesto por Brothwell (1981) para molares. In Les restes humains mésolithiques de l'abri Cornille, Istres (Bouches-du-Rhône), ed. C. Bouville, T. S. Constandse-Westermann, and R. R. Newell, 89-110. Bulletins et Mémoires de la Société d'Anthropologie, Paris, 10, series 13.

Pettitt, P. B., M. P. Richards, R. Maggi, and V. Formicola. 2003. The Gravettian burial known as the Prince ("Il Principe"): New evidence for his age and diet. Antiquity 295: $15-19$.

Polet, C., and M. A. Katzenberg. 2003. Reconstruction of the diet in a mediaeval monastic community from the coast of Belgium. Journal of Archaeological Science 30:525-33.

Richards, M. P. 2000. Human consumption of plant foods in the British Neolithic: Direct evidence from bone stable iso- 
topes. In Plants in Neolithic Britain and beyond, ed. A. Fairbairn, 123-35. Oxford: Oxbow Monographs.

. 2003. Explaining the dietary isotope evidence for the rapid adoption of the Neolithic in Britain. In Food, culture, and identity in the Neolithic and Early Bronze Age, ed. M. Parker-Pearson, 31-36. British Archaeological Reports International Series 1117.

Richards, M. P., and R. E. M. Hedges. 1999a. A Neolithic revolution? New evidence of diet in the British Neolithic. Antiquity 73:891-97.

$\rightarrow \longrightarrow$. 1999b. Stable isotope evidence for similarities in the types of marine foods used by Late Mesolithic humans at sites along the Atlantic coast of Europe. Journal of Archaeological Science 26:717-22.

- n.d. Stable isotope results from the sites of Gerani, Armenoi, and Mycenae. In Archaeology meets science: Biomolecular and site investigations in Bronze Age Greece, ed. H. Martlew, Y. Tzedakis, and M. Jones. Oxford: Oxbow Books. In press.

$\rightarrow$ Richards, M. P., R. E. M. Hedges, I. Walton, S. Stoddart, and C. Malone. 2001. Neolithic diet at the Brochtorff Circle, Malta. European Journal of Archaeology 4:253-62.

Richards, M. P., and P. Mellars. 1998. Stable isotopes and the seasonality of the Oronsay middens. Antiquity 72:178-84.

$\rightarrow$ Richards, M. P., T. I. Molleson, L. Martin, N. Russell, and J. A. Pearson. 2003. Palaeodietary evidence from Neolithic Çatalhöyük, Turkey. Journal of Archaeological Science 30: 67-76.

$\rightarrow$ Richards, M. P., T. D. Price, and E. Koch. 2003. Mesolithic and Neolithic subsistence in Denmark: New stable isotope data. Current Anthropology 44:288-95.

$\rightarrow$ Richards, M. P., R. J. Schulting, and R. E. M. Hedges. 2003. Sharp shift in diet at onset of Neolithic. Nature 425:366.

Richards, M. P., and G. J. van Klinken. 1997. A survey of European human bone stable carbon and nitrogen isotope values. In Archaeological sciences 1995, ed. A. G. M. Sinclair, E. A. Slater, and J. A. J. Gowlett, 363-68. Oxbow Monograph 64.

$\rightarrow$ Schoeninger, M., and M. DeNiro. 1984. Nitrogen and carbon isotopic composition of bone collagen from marine and terrestrial animals. Geochimica et Cosmochimica Acta 48: 625-39.

$\rightarrow$ Schoeninger, M., M. DeNiro, and H. Tauber. 1983. Stable nitrogen isotope ratios of bone collagen reflect marine and terrestrial components of prehistoric human diet. Science 220:1381-83.

$\rightarrow$ Schulting, R. J., and M. P. Richards. 2001. Dating women and becoming farmers: New palaeodietary and AMS dating evidence from the Breton Mesolithic cemeteries of Téviec and Hoëdic. Journal of Anthropological Archaeology 20:314-44. 2002a. Finding the coastal Mesolithic in Southwest Britain: AMS dates and stable isotope results on human remains from Caldey Island, South Wales. Antiquity 76: 1011-25.

$\rightarrow$ - 2002b. The wet, wild, and the domesticated: The Mesolithic-Neolithic transition on the west coast of Scotland. European Journal of Archaeology 5:147-89.

$\rightarrow$ Schwarcz, H. P., T. L. Dupras, and S. I. Fairgrieve. $1999 .{ }^{15} \mathrm{~N}$ enrichment in the Sahara: In search of a global relationship. Journal of Archaeological Science 26:629-36.

SPSS. 2001. SPSS for Windows-release 11.5.1. Chicago.

Stuiver, M., and P. J. Reimer. 1993. Extended ${ }^{14} \mathrm{C}$ database and revised CALIB radiocarbon calibration program. $R a-$ diocarbon 35:215-30.

Stuiver, M., P. J. Reimer, and R. Reimer. 2005. CALIB 5.0.1. WWW Program and documentation.

$\rightarrow$ Tauber, H. $1981 .{ }^{13} \mathrm{C}$ evidence for dietary habits of prehistoric man in Denmark. Nature 292:332-33.

. 1983. ${ }^{13} \mathrm{C}$ dating of human beings in relation to dietary habits. PACT 8:365-75.

1986. Analysis of stable isotopes in prehistoric populations. In Innovative trends in prehistoric archaeology, ed. B. Herrmann, 31-38. Mitteilungen der Berliner Gesellschaft für Anthropologie, Ethnologie and Urgeschichte 7.

Turbón, D. 1987. Epipaleolithic remains from the northeast Iberian Peninsula. In Proceedings of the 2nd Symposium on Upper Paleolithic, Mesolithic, and Neolithic populations of Europe and the Mediterranean basin. Tel-Aviv.

Ubelaker, D. H. 1989. Human skeletal remains: Excavation, analysis, interpretation. Washington, D.C.: Taraxacum.

van Klinken, G. J., M. P. Richards, and R. E. M. Hedges. 2000. An overview of causes for stable isotopic variations in past European human populations: Environmental, ecophysiological, and cultural effects. In Biogeochemical approaches to palaeodietary analysis, ed. S. Ambrose and A. Katzenberg, 39-63. New York: Kluwer Academic/Plenum Publishers.

$\rightarrow$ van Klinken, G. J., H. van der Plicht, and R. E. M. Hedges. 1994. Bone ${ }^{13} \mathrm{C} /{ }^{12} \mathrm{C}$ ratios reflect (palaeo-)climatic variations. Geophysical Research Letters 21:445-48. 